\title{
Endophytic Colonization of Plants by the Biocontrol Agent Rhizobium etli G12 in Relation to Meloidogyne incognita Infection
}

\author{
J. Hallmann, A. Quadt-Hallmann, W. G. Miller, R. A. Sikora, and S. E. Lindow
}

First, second, and fourth authors: Institut für Pflanzenkrankheiten, Phytomedizin in Bodenökosystemen, Nußallee 9, D-53115 Bonn, Germany; third author: U.S. Department of Agriculture-Agriculture Research Services, Food Safety and Health Unit, Albany, CA; and fifth author: Department of Plant and Microbial Biology, University of California, 111 Koshland Hall, Berkeley 94720.

Accepted for publication 19 December 2000.

\section{ABSTRACT}

Hallmann, J., Quadt-Hallmann, A., Miller, W. G., Sikora, R. A., and Lindow, S. E. 2001. Endophytic colonization of plants by the biocontrol agent Rhizobium etli G12 in relation to Meloidogyne incognita infection. Phytopathology 91:415-422.

The external and internal colonization of potato and Arabidopsis roots by the biocontrol strain Rhizobium etli G12 containing a plasmidborne trp promoter green fluorescent protein transcriptional fusion, pGT-trp, was studied in the presence and absence of the root-knot nematode Meloidogyne incognita. Plant colonization behavior and biocontrol potential of the marked strain G12(pGT-trp) was not altered compared with the parental strain. Plasmid pGT-trp was stable for more than 80 generations without selection and conferred sufficient fluorescence to detect single bacterial cells in planta. Although bacteria were found over the entire rhizoplane, they preferentially colonized root tips, the emerging lateral roots, and galled tissue caused by Meloidogyne infestation. Internal colonization of potato roots was mainly observed in epidermal cells, especially root hairs. G12(pGT-trp) colonization was also observed in inner Arabidopsis root tissues in areas of vascularization. In the presence of $M$. incognita, G12(pGT-trp) colonized the interior of nematode galls in high numbers. In some cases, bacterial colonization even extended from the galled tissue into adjacent root tissue. The internally colonized sites in roots were often discontinuous. Fluorescence microscopy of $g f p$ tagged rhizobacteria was a sensitive and a rapid technique to study external and internal colonization of plant roots by bacteria interacting with nematodes.
Endophytic bacteria have recently been a focus of interest as biocontrol agents. Such bacteria are indigenous to most plant species, colonizing the tissue locally or systemically and both intercellularly and intracellularly $(9,22)$. Endophytic bacteria are predominantly recruited from the rhizosphere $(10,19)$ where they presumably use wounds and natural openings to enter the plant. Lytic enzymes produced by these bacteria might also contribute to more efficient penetration and colonization (21). Compared with rhizosphere colonizers, internal colonizers can provide additional benefits as biocontrol agents. Because the plant provides shelter and nutrients, the bacteria can develop under less competitive conditions and shield the plant interior against pathogens. Through bacteria-mediated-induced resistance, the close association formed between endophytic bacteria and the plant might result in a stronger and more persistent plant protection.

Rhizobium etli G12, originally isolated from the rhizosphere of potato, is an antagonist of the potato cyst nematode Globodera pallida (12) and the root-knot nematode Meloidogyne incognita (J. Hallmann, A. Quadt-Hallmann, W. G. Miller, R. A. Sikora, and S. E. Lindow, unpublished data). Antagonism of nematodes by $R$. etli G12 is associated with its ability to induce systemic resistance as demonstrated in a split-root system (12). Recent research has shown that bacterial lipopolysaccharides elicit the resistance mechanism (23). Whereas in previous work $R$. etli G12 was exclusively considered a rhizosphere colonizer, the bacterium was recently re-isolated from the root interior (K. Hasky-Günther and

Corresponding author: J. Hallmann; E-mail address: j.hallmann@uni-bonn.de

Publication no. P-2001-0219-02R

(C) 2001 The American Phytopathological Society
R. A. Sikora, unpublished data). For biocontrol agents that colonize both the rhizosphere and endorhiza, it is difficult to differentiate whether biological control depends on bacterial colonization of the rhizosphere, the endorhiza, or both. Because the ability of bacteria to confer biological control of nematodes probably depends on close proximity between bacteria and nematodes, knowledge of spatial patterns of bacterial colonization is important in understanding biological control.

Because the process of root colonization by endophytic bacteria is not yet fully understood, information on bacterial location in or on the plant could provide further insight into the process of bacterial root colonization. The method that we chose utilizes the green fluorescent protein (GFP), originally isolated from the jellyfish Aequorea victoria. In order to localize $R$. etli cells on and in the root tissue, we required a marker plasmid containing $g f p$ fused to a promoter that is both strong and relatively insensitive to environmental and nutritional signals. A marker plasmid fulfilling these requirements was constructed by inserting the Salmonella typhimurium trp promoter into the promoter-probe plasmid pPROBE-GT (20).

The objectives of this study were to (i) evaluate the potential of GFP as a marker for bacterial colonization of the rhizosphere and especially the endorhiza, (ii) examine endophytic colonization sites, and (iii) evaluate biological control and colonization of $R$. etli G12 cells in nematode-infested root tissue. This research was conducted on beans, potatoes, and Arabidopsis thaliana as host plants and with $M$. incognita race 3 as the pathogen to reflect a variety of natural plant hosts and colonization processes. Because induced resistance by $R$. etli G12 was formerly evaluated against cyst nematodes, preliminary experiments were also conducted to confirm the biocontrol potential of $R$. etli G12 against the rootknot nematode, $M$. incognita. 


\section{MATERIALS AND METHODS}

Plant material. The experiments were conducted with bean (Phaseolus vulgaris cv. Bush Blue Lake 274), potato (Solanum tuberosum cv. Norgold Russet) and Arabidopsis thaliana ecotype Co 1-0. Bean and potato plants were grown in a soil-silica sand mixture $(1: 1, \mathrm{vol} / \mathrm{vol})$ in a greenhouse at 25 to $28^{\circ} \mathrm{C}$ for 30 days prior to use. The field soil used was a sandy loam $(\mathrm{pH} 6.5)$ and $1.5 \%$ organic matter. Plants were watered weekly with $10 \mathrm{ml}$ of Peter's solution (20-20-20, Scotts-Sierra, Maryvilles, OH). Arabidopsis thaliana was grown in the greenhouse with a commercial planting substrate (Sunshine Mix; Sun Gro Horticulture Inc., Bellevue, WA) containing peat moss and perlite. Furthermore, bean plants were grown under gnotobiotic conditions in test tubes containing silica sand as growth substrate. Test tubes $(2.2 \times 20 \mathrm{~cm})$ were filled with $50 \mathrm{~g}$ of silica sand (Crystal Silica Company, Oceanside, CA) that was moistened by adding $10 \mathrm{ml}$ of water and then autoclaved. Bean seeds were surface disinfested $(5 \mathrm{~min}$ in $1.05 \% \mathrm{NaOCl}$ ) and washed three times with sterile $0.01 \mathrm{M}$ sodium phosphate buffer (PB) $(\mathrm{pH} 7.0)$. One seed was planted in each test tube, and test tubes were placed in a greenhouse.

Bacterial inoculum. $R$. etli strain G12 (formerly described as Agrobacterium radiobacter strain G12) (12) was originally isolated from a potato rhizosphere (23). A spontaneous rifampicinresistant mutant of $R$. etli $\mathrm{G} 12$ and its gfp-tagged variant $R$. etli G12 (pGT-trp) were used in all studies. If not otherwise stated, bacteria were cultured on Luria-Bertani agar (LA) (Life Technologies, Gaithersburg, MD) or broth (LB) (Life Technologies) in the dark at $27^{\circ} \mathrm{C}$ for $48 \mathrm{~h}$ before use. Bacterial suspensions for plant or soil inoculation were diluted to an optical density at $600 \mathrm{~nm}\left(\mathrm{OD}_{600}\right)=0.4$, representing $1.1 \times 10^{9} \mathrm{CFU} / \mathrm{ml}$.

GFP expression plasmids and bacterial transformation. The GFP expression plasmid pGT-trp was constructed by inserting a 154-bp HindIII fragment from pVO131 (8), containing the Salmonella typhimurium trp promoter, into the unique HindIII site of pPROBE-GT (20). pPROBE-GT is a broad host-range plasmid that confers gentamycin resistance and is maintained at approximately 5 to 10 copies per cell. The $g f p$ allele in pPROBE-GT includes the S65T "red-shift" mutation (14) and the F64L mutation, which increases protein solubility (3). This allele has an emission maximum at $510 \mathrm{~nm}$ and an excitation maximum at $490 \mathrm{~nm}$. The presence of the trp promoter in pGT-trp was verified by restriction analysis. pGT-trp was mobilized into $R$. etli G12 by triparental

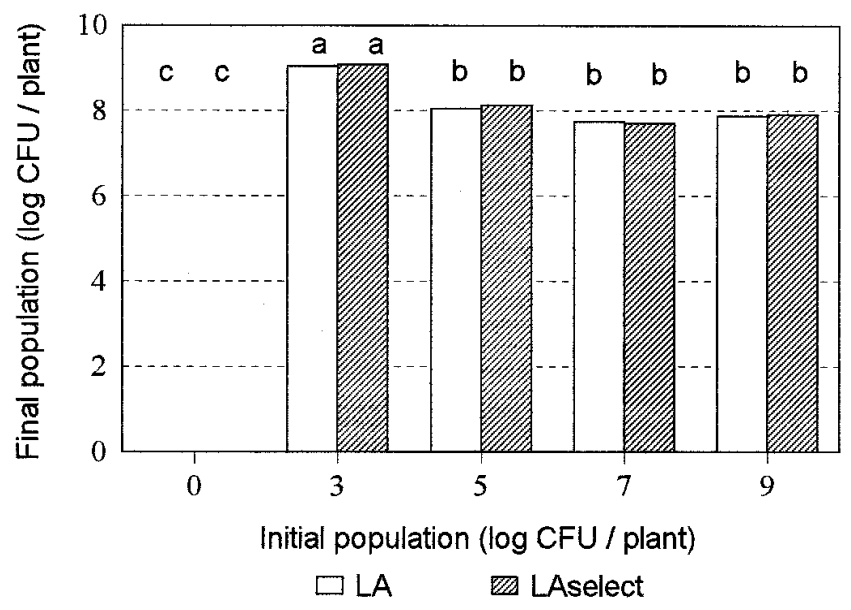

Fig. 1. Multiplication of Rhizobium etli G12(pGT-trp) on bean plants. R. etli G12 and G12(pGT-trp) were inoculated at the concentrations shown on the abscissa in a gnotobiotic system onto bean seedlings, and bacterial population sizes were determined 7 days later on Luria-Bertani agar (LA) and LA containing $15 \mu \mathrm{g}$ of gentamycin per $\mathrm{ml}$ (LA select). Treatments with the same letter are not significantly different according to Duncan's multiple range test $(P=0.05 ; N=4)$. mating with DH5 $\alpha$ (pGT-trp) as the donor strain and DH5 $\alpha$ (pRK2013) (5) as the helper strain. Midlog cultures of the donor, helper, and recipient strains were mixed at a ratio of either 1:1:1 or 1:1:10 (donor/helper/recipient), spotted onto LA plates, and incubated overnight at $28^{\circ} \mathrm{C}$. The mating spots were then restreaked onto LA amended with $15 \mu \mathrm{g}$ of gentamycin per $\mathrm{ml}$ (Sigma Chemicals, St. Louis) and $100 \mu \mathrm{g}$ of rifampicin per $\mathrm{ml}$ (Sigma Chemicals) and examined for fluorescence after 1 to 2 days.

Plasmid stability and fluorescence intensity. Plasmid stability was assessed in the absence of the selectable gentamycin-resistance marker by growing G12(pGT-trp) for 80 generations in LB. The culture was started by adding $500 \mu \mathrm{l}$ of a bacterial suspension of $\approx 10^{6} \mathrm{CFU} / \mathrm{ml}$ into $4.5 \mathrm{ml}$ of LB. After $24 \mathrm{~h}$ at $27^{\circ} \mathrm{C}$, when the bacterial population reached $\approx 10^{9} \mathrm{CFU} / \mathrm{ml}$, serial dilutions were prepared, plated on both LA and LA supplemented with $15 \mu \mathrm{g}$ of gentamycin per $\mathrm{ml}$, and colony counts were compared. Five hundred microliters of a 1:100 dilution was transferred to $4.5 \mathrm{ml}$ of $\mathrm{LB}$, and the process was repeated nine times, at which time approximately 80 bacterial generations occurred.

The stability of pGT-trp in G12 was also confirmed in situ on bean plants grown in a gnotobiotic system as described previously. Five-day-old seedlings were inoculated with $1 \mathrm{ml}$ of G12(pGT-trp) at $10^{3}, 10^{5}, 10^{7}$, or $10^{9} \mathrm{CFU} / \mathrm{ml}$. Each treatment was replicated four times, and a buffer-inoculated treatment served as a control. The plants were grown in the greenhouse at 25 to $28^{\circ} \mathrm{C}$ with a 16-h photoperiod. After 7 days, the shoots of the bean plants were removed and roots with adhering sand were transferred into $125-\mathrm{ml}$ flasks containing $50 \mathrm{ml}$ of PB. The flasks were shaken on a rotary shaker at $150 \mathrm{rpm}$ for $30 \mathrm{~min}$. The soil suspension was serially diluted and plated on LA and LA supplemented with $15 \mu \mathrm{g}$ of gentamycin per $\mathrm{ml}$ and $100 \mu \mathrm{g}$ of rifampicin per $\mathrm{ml}$. Roots were blotted dry with a paper towel, and fresh weight was determined.

To measure fluorescence intensity, both G12 and G12(pGT-trp) were grown on LA for $40 \mathrm{~h}$ at $28^{\circ} \mathrm{C}$. Cells were scraped from the plate, suspended in $0.01 \mathrm{M} \mathrm{PB}$, washed once in $\mathrm{PB}$, and diluted to an $\mathrm{OD}_{600}$ between 0.5 and 1.0. GFP fluorescence intensities of bacterial suspensions were determined with a luminescence spectrometer (Model LS50B; Perkin-Elmer, Beaconsfield, U.K.) with an excitation wavelength of $490 \mathrm{~nm}$ and emission wavelength of $510 \mathrm{~nm}$. A slit width of $8 \mathrm{~nm}$ was used for both excitation and emission. Intensity readings in arbitrary units were normalized to a cell density of $10^{9}$ cells per $\mathrm{ml}$. Three replicate cultures were analyzed for each strain.

Fluorescence of G12(pGT-trp) cultures were repeatedly measured to determine how fast fluorescence develops over time and how stable it is after cell multiplication occurred. Therefore, 12 LA plates were divided into three sections each and a single colony from a starter culture of G12(pGT-trp) was streaked onto each section. Samples were taken twice daily for 7 days, and fluorescence intensity was measured as described previously. At each sampling time, one LA plate was processed with each of three single colonies per plate serving as a replication.

Rhizosphere and endophytic colonization. The experiment was conducted to compare the ecological fitness between G12 and G12(pGT-trp). Sprouts approximately $1 \mathrm{~cm}$ long and some adjacent tuber tissue were cut from pregerminated potato tubers and incubated in a bacterial suspension of G12(pGT-trp) $\left(\mathrm{OD}_{600}=0.4\right)$ for $30 \mathrm{~min}$ prior to planting in plastic pots filled with $400 \mathrm{ml}$ of a soil-silica sand mixture $(1: 1, \mathrm{vol} / \mathrm{vol})$. Control cuttings were incubated in PB. The plants were kept in a greenhouse at 25 to $28^{\circ} \mathrm{C}$ with a 16-h photoperiod. Each treatment was replicated eight times, and the experiment was repeated two times. After 21 days, sprouts were separated from roots and fresh weight was determined. Roots were removed from the soil and weighed with adhering soil. Roots were transferred into flasks containing $50 \mathrm{ml}$ of $\mathrm{PB}$ and shaken at $150 \mathrm{rpm}$ for $30 \mathrm{~min}$ to separate soil from roots. The roots were removed from the flasks and washed under run- 
ning tap water for $30 \mathrm{~s}$. The remaining soil in the flask (considered rhizosphere soil) was serially diluted and streaked onto LA and LA supplemented with $15 \mu \mathrm{g}$ of gentamycin per $\mathrm{ml}$ and $100 \mu \mathrm{g}$ of rifampicin per $\mathrm{ml}$. The population of indigenous bacteria and introduced bacteria was determined, respectively. The roots were blotted dry on a paper towel, root fresh weight was recorded, and roots were surface disinfested in $1.05 \% \mathrm{NaOCl}$ plus $0.01 \%$ Tween 20 (Sigma Chemicals) for $3 \mathrm{~min}$, followed by three washes in sterile PB. The roots were imprinted on tryptic soy agar (Life Technologies) as a check for sterility. Roots were transferred into a mortar, $3 \times$ PB (vol/wt) was added, and ground. The macerate was serially diluted and streaked on LA and LA supplemented with either $100 \mu \mathrm{g}$ of rifampicin per ml to detect G12 or $15 \mu \mathrm{g}$ of gentamycin per ml plus $100 \mu \mathrm{g}$ of rifampicin per $\mathrm{ml}$ to detect G12(pGT-trp).

Biological control. Potato tuber cuttings with one pregerminated sprout each were soaked in a bacterial suspension $\left(\mathrm{OD}_{600}=\right.$ 0.4 ) of G12 or G12(pGT-trp) for $30 \mathrm{~min}$ and planted into plastic pots containing $400 \mathrm{ml}$ of soil-silica sand mixture (3:1, vol/vol). Control plants were soaked in PB. Plants were grown in the greenhouse at 25 to $28^{\circ} \mathrm{C}$ with a 16-h photoperiod. After 2 weeks, plants were inoculated with $3 \mathrm{ml}$ of a bacterial suspension $\left(\mathrm{OD}_{600}=0.4\right)$ at three spots around the base of the stem. Three days later, potatoes were inoculated with 3,000 eggs of $M$. incognita race 3 extracted from tomato roots using $\mathrm{NaOCl}$ (17). Eggs were separated from plant debris by passing the egg suspension successively through sieves of 100- and 38- $\mu \mathrm{m}$ mesh. The egg suspension was adjusted to 1,000 eggs per $\mathrm{ml}$ by adding tap water, and a total of $3 \mathrm{ml}$ was inoculated at three spots around the stem base. Seven weeks after bacterial inoculation, the fresh weight of sprouts and roots was taken as described previously and the number of Meloidogyne galls was counted. The experiment consisted of four treatments: (i) control, (ii) inoculation with $M$. incognita, (iii) pretreatment with G12 and inoculation with $M$. incognita, and (iv) pretreatment with G12(pGT-trp) and inoculation with $M$. incognita. The experiment was arranged as a complete randomized block. Each treatment was replicated eight times, and the experiment was repeated once.

Bacterial localization in roots. All studies on bacterial localization were done with G12(pGT-trp) on potato or Arabidopsis. Pregerminated potato tubers with sprouts of $\approx 1 \mathrm{~cm}$ long were cut and soaked in a bacterial suspension $\left(\mathrm{OD}_{600}=0.1\right)$ for $30 \mathrm{~min}$ as described previously. The seedlings were also treated with $3 \mathrm{ml}$ of a bacterial suspension $\left(\mathrm{OD}_{600}=0.4\right)$ as a soil drench 5 days after planting. For Arabidopsis plants, only a soil drench with $3 \mathrm{ml}$ of the bacterial suspension $\left(\mathrm{OD}_{600}=0.4\right)$ was applied to 3 -week-old plants. $M$. incognita was inoculated with 3,000 juveniles 2 days after the bacterial soil drench. Eggs of $M$. incognita were extracted as described previously and agitated in tap water for 10 days to stimulate juvenile hatching. The infectious second-stage juveniles were extracted by a modified Baerman technique and adjusted to 1,000 juveniles per $\mathrm{ml}$ by diluting with tap water. A total of $3 \mathrm{ml}$ of the juvenile suspension was inoculated at three spots around the stem base of each plant. Samples for microscopy were taken 10 days after nematode inoculation. Roots were carefully removed from the soil and transferred to a glass petri dish filled with tap water. After adhering soil particles were removed, roots were cut into 1- to 2-cm pieces and observed directly by either epifluorescence microscopy (Zeiss Axiophot, Carl Zeiss Inc., Oberkochen, Germany), with a band pass excitation filter BP450-490 and a barrier emission filter LP520, or by confocal laser scanning microscopy (CLSM) (Nikon, Melville, NY) with a 488-nm Argon ion laser and a EFLP530 barrier filter. The entire root system was examined for fluorescent bacteria and the number of fluorescent galls. Noninoculated and nematode-free plants, as well as G12(pGTtrp) inoculated but nematode-free plants, served as controls. In order to work with fresh plant material, potato and Arabidopsis were repeatedly grown in 10-day intervals for 1 month.
Statistical analysis. Bacterial population sizes were log transformed and analyzed according to standard analysis of variance procedures with the software Statgraphics (Statistical Graphics Corp., Rockville, MD). Duncan's multiple range test was used for mean comparisons. Variance homogeneity for all treatments was confirmed by the Bartlett test. Statistical differences referred to in the text were significant at $P=0.05$.

\section{RESULTS}

Plasmid stability and fluorescence intensity. Plasmid stability of pGT-trp in G12 grown in LB was confirmed by plating G12(pGT-trp) side by side on LA and LA supplemented with $15 \mu \mathrm{g}$ of gentamycin per ml (data not shown). The population densities of G12(pGT-trp) were the same on both media for up to 80 bacterial generations being tested. Nonfluorescent colonies of G12(pGT-trp) appeared after 18 bacterial generations on both media, accounting for $1.8 \%$ of the total population and increased to approximately $12.5 \%$ after 80 generations.

Plasmid stability was additionally tested in a gnotobiotic system on bean plants. The final bacterial densities on all inoculated plants ranged from $\log 7.71$ to $9.07 \mathrm{CFU}$ per plant (Fig. 1). For each inoculum density, the final bacterial populations on LA or LA supplemented with $15 \mu \mathrm{g}$ of gentamycin per ml were the same, confirming plasmid stability. The highest final population per plant ( $\log 9.07 \mathrm{CFU}$ ) was achieved for the treatment receiving the lowest inoculum $\left(10^{3} \mathrm{CFU}\right)$, reflecting approximately 23 generations.

Fluorescence by G12(pGT-trp) was readily detected in a fluorimeter after cell populations exceeded approximately $10^{9}$ cells per $\mathrm{ml}$ (Fig. 2). The fluorescence of individual bacterial cells was clearly visible with a fluorescence microscope (Fig. 3A and B). Fluorescence developed over time and reached its maximum after approximately $40 \mathrm{~h}$ (Fig. 2).

Rhizosphere and endophytic colonization. The ecological fitness of G12(pGT-trp) was similar to wild-type G12 on potato as determined from rhizosphere and endophytic colonization. The total rhizosphere bacterial numbers on both control plants and plants inoculated with G12 or G12(pGT-trp) were approximately $\log 7.4$ and did not differ among treatments. The total endophytic bacterial numbers from those three treatments were approximately $\log 4.0$ and did not differ (Fig. 4). G12 and G12(pGT-trp) reached similar population sizes in the rhizosphere and represented 11.1 and $23.3 \%$ of the total population, respectively. For the endorhiza, populations did not differ and represented 4.2 and $1.0 \%$ of the indigenous population, respectively.

Biological control. Experiments were conducted to determine if expression of GFP fluorescence affects the biocontrol potential of $R$. etli G12(pGT-trp) toward M. incognita on potato. Both G12

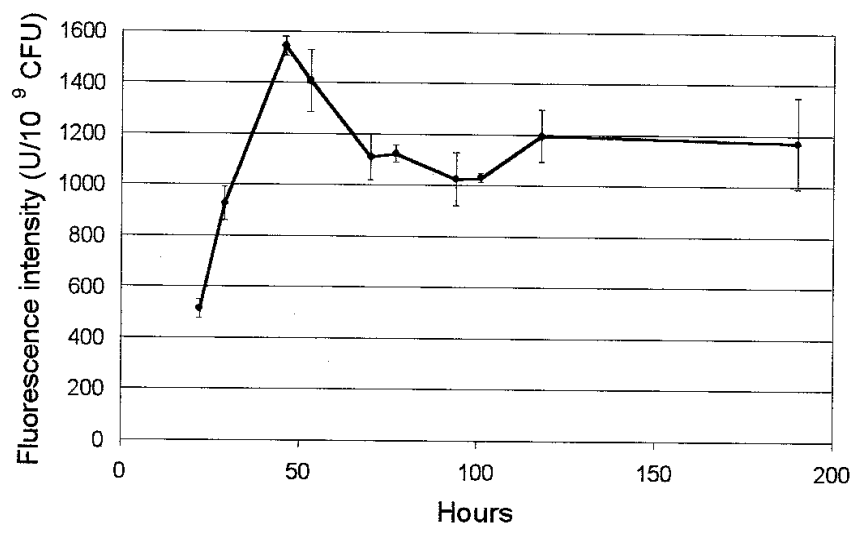

Fig. 2. Fluorescence of Rhizobium etli G12(pGT-trp) over time. Fluorescence intensity values represent arbitrary units provided by the fluorimeter normalized to a cell density of $10^{9}$ cells per ml. Each data point represents the mean of three independent samples, and bars represent the standard deviation. 
and G12(pGT-trp) significantly decreased the number of galls formed by $M$. incognita on potato (Fig. 5). The number of galls on roots following treatment with G12 and G12(pGT-trp) was 34 and $39 \%$ lower, respectively, than on roots treated with $M$.
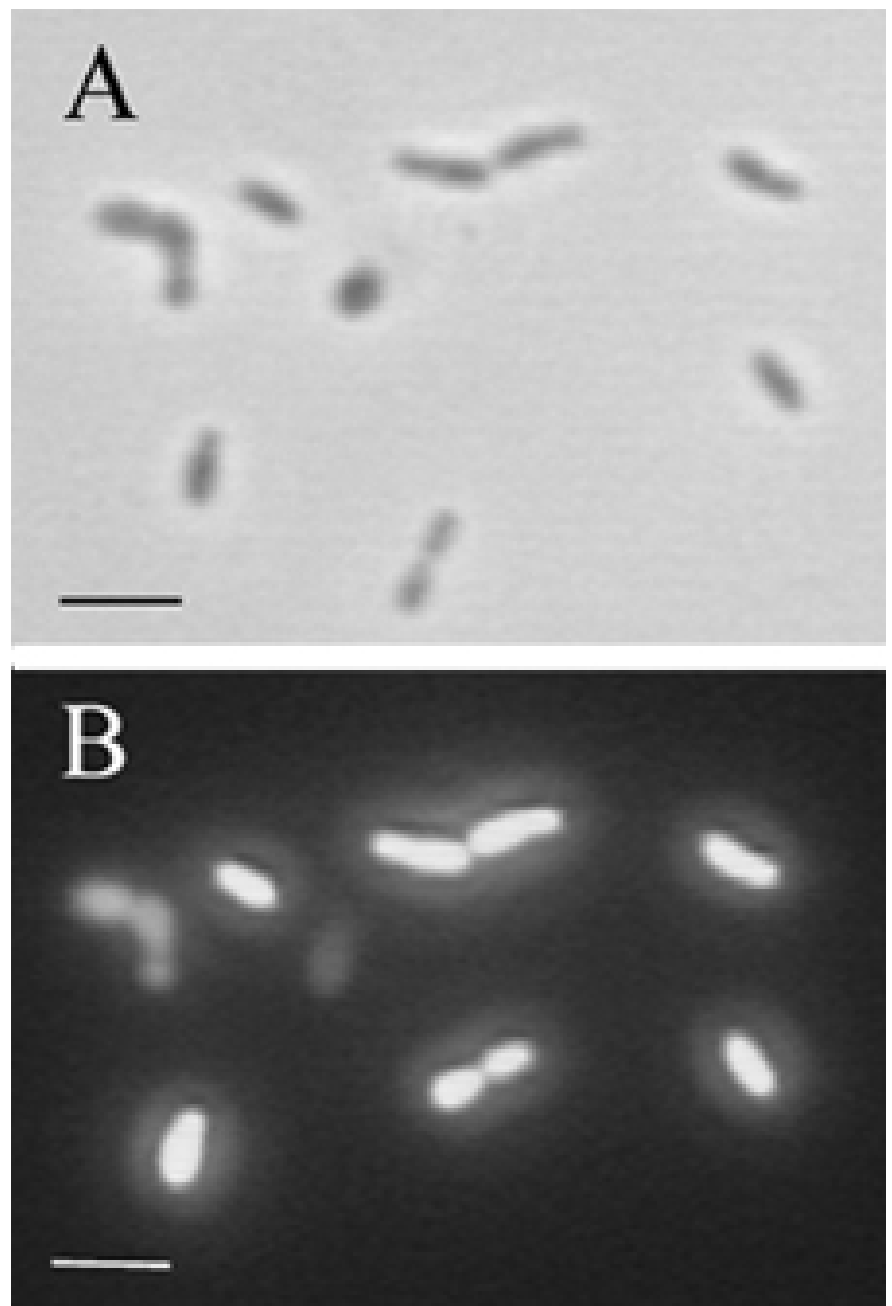

Fig. 3. A, Bright field and B, epifluorescence images of Rhizobium etli G12(pGT-trp) cultured in Luria-Bertani broth at $27^{\circ} \mathrm{C}$ for $48 \mathrm{~h}$. Slight differences in bacterial location are due to cell motility. Magnification bars represent $5 \mu \mathrm{m}$.

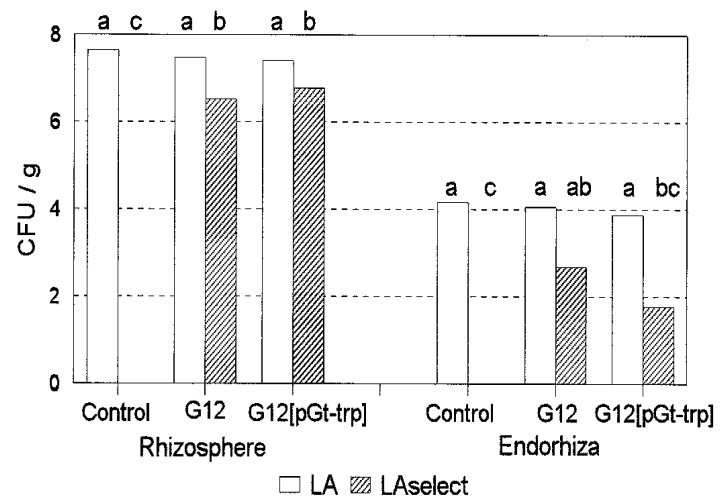

Fig. 4. Total bacterial numbers and numbers of Rhizobium etli G12 and G12(pGT-trp) in the rhizosphere and endorhiza of inoculated potato plants. Total bacterial populations determined 21 days after inoculation on LuriaBertani agar (LA) and populations of G12 recovered on LA containing $100 \mu \mathrm{g}$ of rifampicin per ml or G12(pGT-trp) recovered on LA containing $100 \mu \mathrm{g}$ of rifampicin per $\mathrm{ml}$ and $15 \mu \mathrm{g}$ of gentamycin per $\mathrm{ml}$ (LA select) are shown for rhizosphere and endorhiza samples. Treatments with the same letter are not significantly different according to Duncan's multiple range test $(P=0.05 ; N=8)$. incognita alone. The difference in number of galls between the two bacterial-inoculated treatments was not significant. Bacterial inoculation had no effect on shoot and root fresh weight (data not shown).

Bacterial location. Although G12(pGT-trp) appeared to colonize most of the potato root surface, they were predominantly found at the root tip (Fig. 6A), near wounds caused by the formation of lateral roots (Fig. 6B) and in association with root epidermal cells, including root hairs (Fig. 6C). Time-lapse studies of G12(pGT-trp) showed bacterial movement within the root hairs (data not shown). Internal colonization of the potato root cortex or vascular tissue was not observed.

As on potato, G12(pGT-trp) on Arabidopsis was scattered over the rhizoplane and preferentially colonized root tips (Fig. 7A), the lateral root base, and root epidermal cells of Arabidopsis (Fig. 7B). Epidermal cells colonized by G12(pGT-trp) were often packed with bacteria, whereas adjacent cells were free of intracellular colonization (Fig. 7B). In addition to the colonization sites observed for potato, G12(pGT-trp) also colonized internal root tissues of Arabidopsis, primarily in or near vascular tissue (Fig. 7C to E). Bacterial microcolonies within the root vascular system formed either a discontinuous (Fig. 7C) or a more continuous (Fig. 7D) chain that became clearly visible at higher magnification (Fig. 7E). Although epifluorescence microscopy images indicated bacterial colonization of the root interior in general, CLSM allowed the specific localization of the bacteria within the root tissue. The internal location of many bacteria was apparent in series of images of optical thin sections taken at 0,40 , and $70 \mu \mathrm{m}$ depth, with the first representing the root surface and the latter representing the root center (Fig. 8A to C). No GFP fluorescence was observed in nontreated roots.

Co-application of M. incognita and G12(pGT-trp) to Arabidopsis roots was associated with increased areas of GFP fluorescence, especially at juvenile penetration sites and nematode galls (Fig. 9A to $\mathrm{G})$. A nematode gall with a penetrating juvenile is shown in the bright field (Fig. 9A) and corresponding epifluorescence image (Fig. 9B). A series of CLSM images shows sections of this gall at 0,80 , and $150 \mu \mathrm{m}$ depth with the first representing the root surface and the latter representing the root center (Fig. 9C to E). No GFP fluorescence was observed at the root surface, but individual GFP fluorescent colonies were visible at $80 \mu \mathrm{m}$ depth and intense microbial colonization was apparent at $150 \mu \mathrm{m}$ depth. Several strings of bacteria extended from the root gall into the adjacent root tissue. However, only approximately $20 \%$ of all galls were colonized by G12(pGT-trp), and colonized galls were randomly distributed over the root system. Galls or lateral roots in close proximity to a colonized gall were often free of fluorescence (Fig. 9F), again indicating the heterogeneous and discontinuous

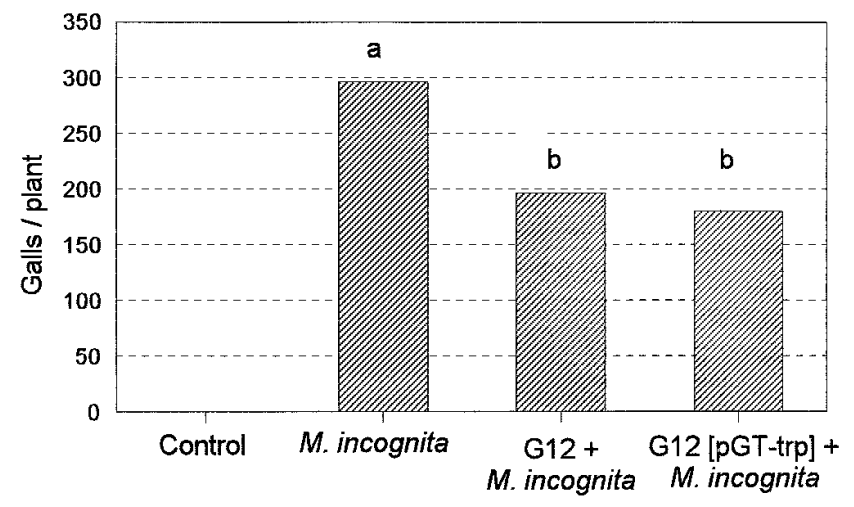

Fig. 5. Effect of Rhizobium etli G12 and G12(pGT-trp) pretreatment on the number of galls formed by Meloidogyne incognita on potato. Treatments with the same letter are not significantly different according to Duncan's multiple range test $(P=0.05 ; N=8)$. 
colonization pattern of G12(pGT-trp). At later stages of nematode development, premature adults sometimes broke through the root epidermis with their anterior region and their head still attached to the nematode feeding site as shown in Figure 9G. This area of epidermal rupture was heavily colonized by G12(pGT-trp). None of the nontreated control plants showed GFP fluorescence.

\section{DISCUSSION}

Endophytic bacterial biocontrol agents can be divided into two groups: (i) strains that extensively colonize the internal plant tissues and suppress invading pathogens by niche occupation, antibiosis, or both, and (ii) strains that primarily colonize the root cortex where they stimulate general plant defense/resistance mechanisms. More extensive and continuous colonization of plants might be required for endophytes of the first type because coincidence with pathogen propagules would be necessary for antagonism. To associate strategies of biological control with colonization patterns, we need to know more about bacterial localization and translocation within the plant tissue, especially when challenged with a plant pathogen. To avoid time-consuming preparations of the plant samples, such as embedding in resins for transmission electron microscopy or staining with fluorescent dyes, we used $g f p$ marker genes to study endophyte interactions with the root-knot nematode $M$. incognita. Bacterial cells transformed with pGT-trp containing a trp-gfp transcriptional fusion expressed high levels of GFP. This plasmid was quite stable in $R$. etli G12; only a few nonfluorescent colonies appeared over time
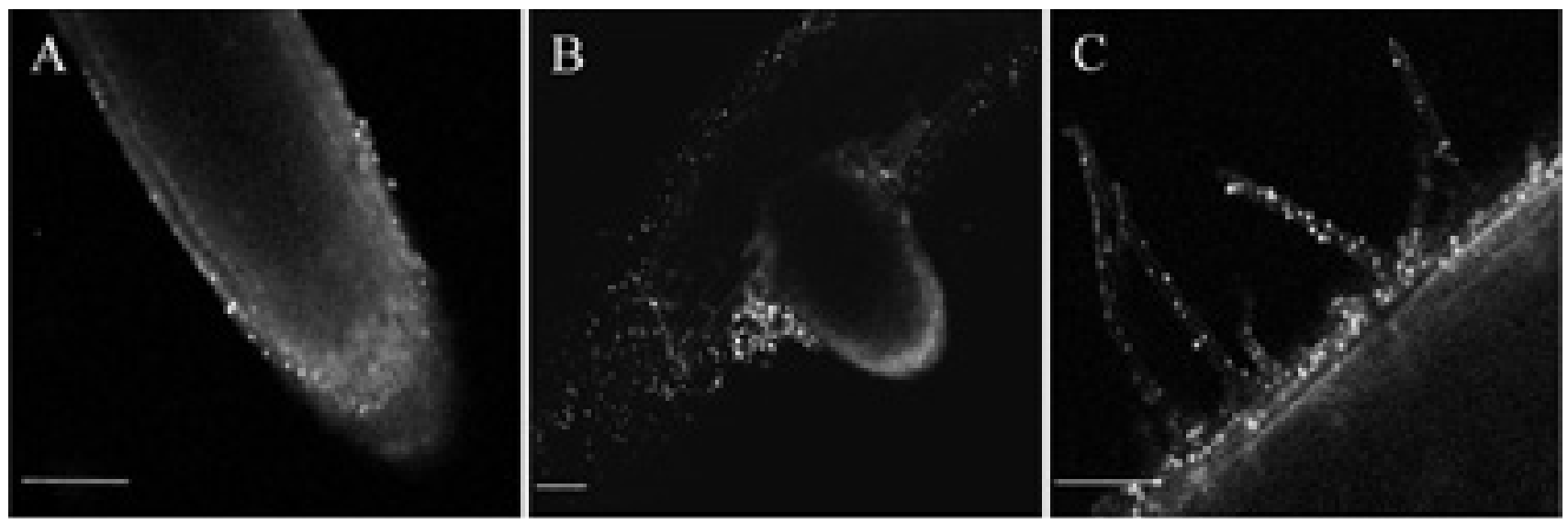

Fig. 6. Visualization of Rhizobium etli G12(pGT-trp) colonizing potato roots by confocal laser scanning microscopy. Potatoes were grown in silica sand, and the root system was analyzed 10 days after bacterial inoculation. A, Colonization by G12(pGT-trp) present at root tips; B, lateral root bases; and $\mathbf{C}$, associated with epidermal cells and root hairs. Magnification bars represent $100 \mu \mathrm{m}$.
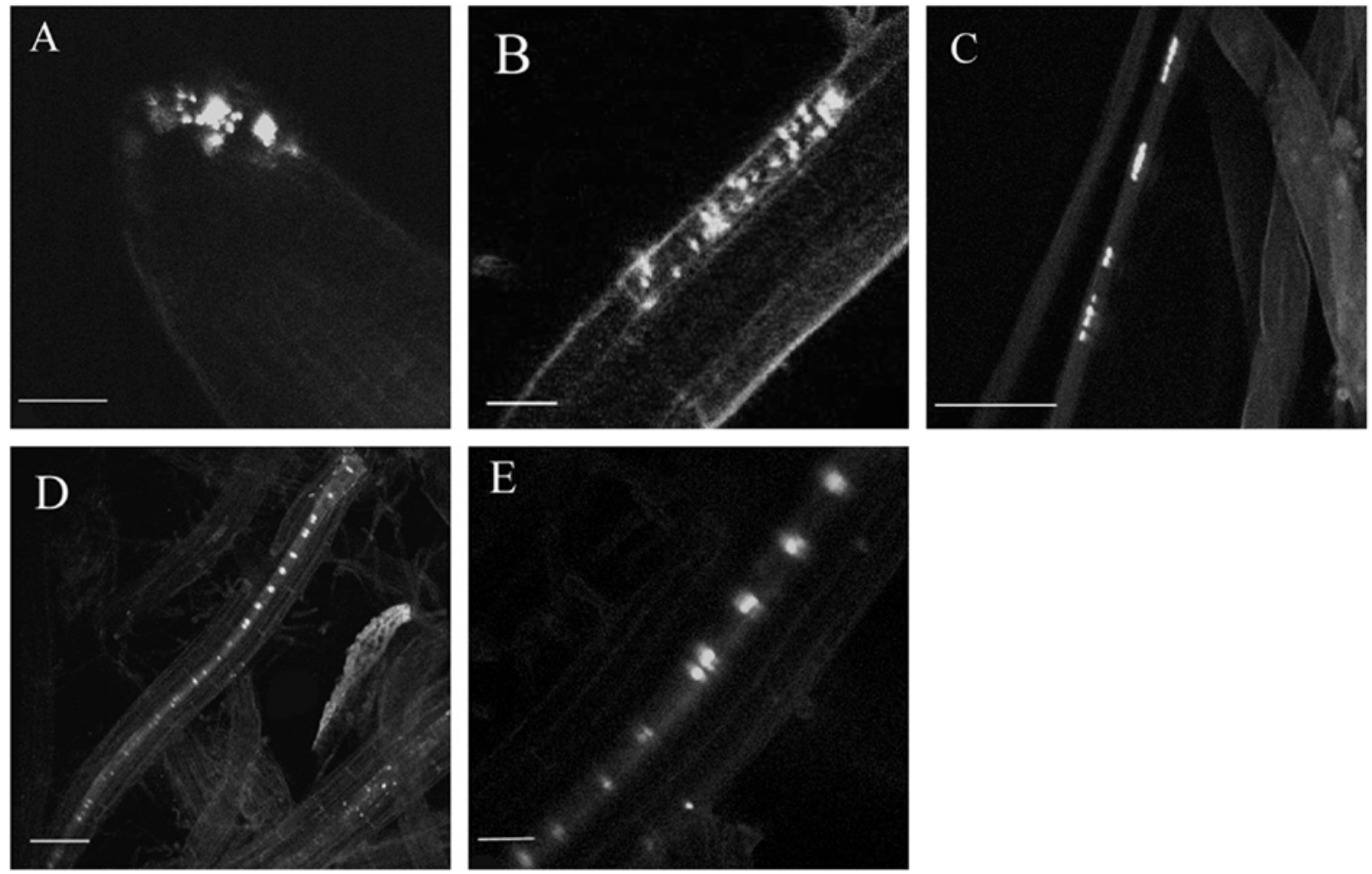

Fig. 7. Visualization of Rhizobium etli G12(pGT-trp) colonizing Arabidopsis roots by confocal laser scanning microscopy. Bacterial colonization of roots was visualized 10 days after inoculation. A, Colonization by G12(pGT-trp) on surface of root tips; B, tightly packed within root epidermal cells; C, forming an uneven string of microcolonies within the root center; $\mathbf{D}$, forming an even string of microcolonies within the root center over a distance representing at least $1 \mathrm{~cm}$; and $\mathbf{E}$, close up of $\mathbf{D}$, showing microcolonies within the root center. $\mathbf{B}, \mathbf{C}$, and $\mathbf{E}$, Magnification bars represent $20 \mu \mathrm{m}$, and $\mathbf{A}$ and $\mathbf{D}, 100 \mu \mathrm{m}$. 
and increased to approximately $12.5 \%$ of the total bacterial population after 80 generations. The importance of nonfluorescent phenotypes occurring under field conditions is less important for short-term studies because rarely are more than 10 generations produced within a season, but should be considered when tracking bacteria over longer times. Fluorescence of G12(pGT-trp) was exhibited soon after cell formation and was maintained at high levels for over 8 days. The growth rate of the $g f p$-marked strains and its biocontrol potential were not altered compared with the wild type, although $g f p$-marked strains exhibited a strong fluorescent signal. These results are in agreement with Bloemberg et al. (2), who also compared growth of Pseudomonas strains with and without GFP-encoding plasmids. Overall, the GFP marker gene was useful for tagging G12.

Because the native GFP used in this study has a very long half life ( $>7$ days), GFP fluorescence would likely be seen in cells, even those that died within this time frame. The GFP marker thus provides information on where bacterial cells are, even if they are dead. Importantly, because plant tissues do not need to be treated in any way before visualizing GFP fluorescence, the location of cells is not disturbed during fluorescence microscopy as in other staining techniques.

The rhizoplane of potato and Arabidopsis, in general, was colonized sporadically and heterogeneously by individual cells of G12(pGT-trp). Preferred colonization sites were root regions that had been associated with high rates of nutrient leakage, including root tips or wounded sites due to lateral root or nematode gall formation. Surface microcolonies, as reported for Azospirillum brasilense on wheat roots (24) or Pseudomonas fluorescens on barley roots (11), were not observed. These findings, in general, confirm previous studies made with other rhizobacteria by standard microscopy with various staining procedures (7). However, the GFP tagging allowed rapid examination of many samples and required none of the pretreatments necessary for fluorescent staining, B-galactosidase activity, or the lux system (18).

$R$. etli G12(pGT-trp) frequently colonized epidermal cells including root hairs of potato and Arabidopsis. These results agree with reports for bacterial symbiont colonization of plants, including colonization of alfalfa roots by $R$. meliloti (8) or wheat roots by Azospirillum brasilense (1). R. etli G12(pGT-trp) colonized isolated epidermal cells; adjacent cells were not colonized. The epidermal cells colonized by $R$. etli G12(pGT-trp) were usually tightly packed with bacteria, confirming observations made by Egener et al. (6) for Azoarcus sp. BH72 colonizing rice roots. Hurek et al. (16) assumed that the bacterium colonized degenerated epidermal cells. However, if colonization of epidermal cells occurred through wounds or micropores we would simultaneously expect leakage of nutrients through those openings, making it difficult to explain such high bacterial numbers only within the epidermal cells. High bacterial populations can only be attained when a continuous supply of nutrients as well as removal of bacterial metabolites occur. It is hypothesized that nutrient supply may result from phloem unloading and nutrient passage through adjacent cells into the host cell, or the endophytic bacterium itself can influence the membrane potential of the neighboring cells to stimulate nutrient secretion into the host cell, a process apparently mediated by extracellular polysaccharides of pathogenic bacteria (4).

Unfortunately, the opacity of the potato roots made observations of bacteria deeper within the root cortex or vascular tissue impossible. Several clearing procedures were tested to increase root transparency. Although treatment with chloral hydrate or a combination of boiling, incubation in $95 \%$ ethanol, and incubation in 5\% $\mathrm{KOH}$ at 37 or $60^{\circ} \mathrm{C}$ resulted in hyaline roots, these techniques destroyed GFP fluorescence. For that reason, Arabidopsis with its transparent roots was chosen as the host plant for further investigation of the internal colonization of G12(pGT-trp).

Microcolonies of G12(pGT-trp) were observed within Arabidopsis roots and appeared to be heterogeneously distributed throughout the root system. CLSM of selected root sections revealed a strong fluorescent signal, the size of one or several plant cells in the center of the root, indicating colonization of the vascular region. However, it could not be determined if the vascular tissue or the surrounding intercellular spaces were colonized. The uniformly sized, clearly delimited regions of high bacterial abundance strongly suggests that bacterial colonization was primarily intracellular; however, further microscopic analysis of colonized areas is necessary to view exact bacterial localization, e.g., by looking at semi- or ultrathin sections with light or transmission electron microscopy. Our results, however, suggest that colonization of the internal parts of roots is not an "infectious" process, in that the presence of large numbers of cells does not appear to be associated with colonization of adjacent cells. Given the large numbers of small and discontinuously colonized sites observed in roots, colonization sites might result from (i) occasional bacterial invasion of the root and efficient colonization of certain cells that bacteria come into contact, or (ii) frequent entry of bacterial cells into a root, their movement through the root but infrequent penetration of root cells, or both. Our results tend to support the first scenario, in which we found few cells of G12(pGT-trp) in roots that were not associated with microcolonies. The need of nutrients for endophytic bacteria to form microcolonies might explain their heterogeneous localization, because nutrients are continuously translocated within the apoplast and adsorbed or fixed to cell wall components (25) of some cells but not others.
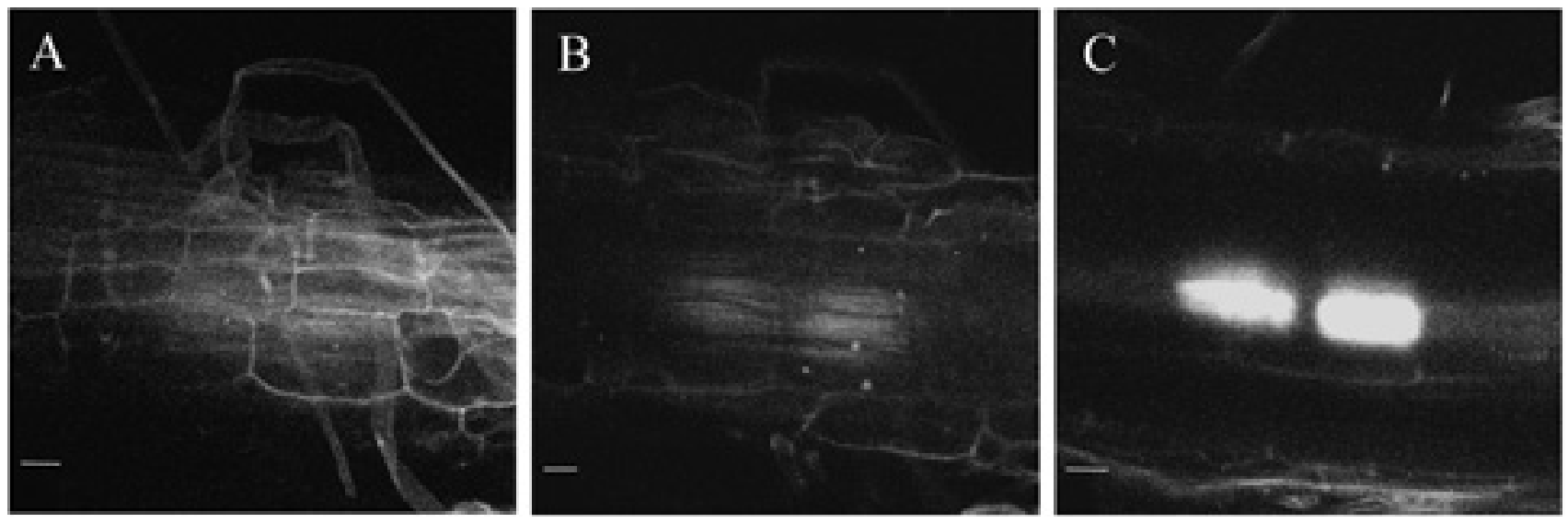

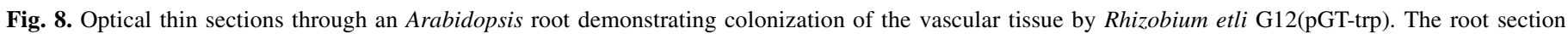

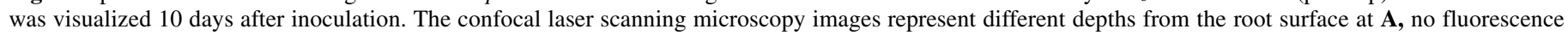

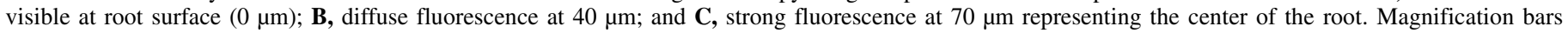
represent $20 \mu \mathrm{m}$. 
G12(pGT-trp) colonized approximately $20 \%$ of the nematode galls. For some galls, bacterial colonization extended from the galls for approximately $1 \mathrm{~cm}$ acropetally, indicating bacterial movement from the galled tissue toward the stem base. This interpretation presupposes initial endophytic infection via wounds caused by juvenile penetration. In fact, large bacterial numbers were often near penetrating juveniles and within galled tissue, indicating leakage of nutrients that became available to the bacteria. In addition, nematode-induced giant cells in galled tissue act as a metabolic sink and contain four to six times more glucose and free amino acids than the actively growing root tip cells (15). Because these nutrients have to be transported from the surrounding tissue into the giant cells, it is possible that endophytic bacteria intercept and use those nutrients. Bacterial uptake of nutrients would then reduce the nutrients available to the nematode and may, therefore, interfere with nematode development and reduce egg production. Nutrient competition is a potential mechanism for suppression of plant-parasitic nematodes by endophytic bacteria (9).

Both G12 and G12(pGT-trp) contributed significantly to the total bacterial rhizosphere population 3 weeks after inoculation, but only marginally to the endophytic population. These data confirm previous results characterizing $R$. etli as a rhizosphere colonizer with endophytic potential (K. Hasky-Günther and R. A. Sikora, unpublished data). Although G12 was originally described as an
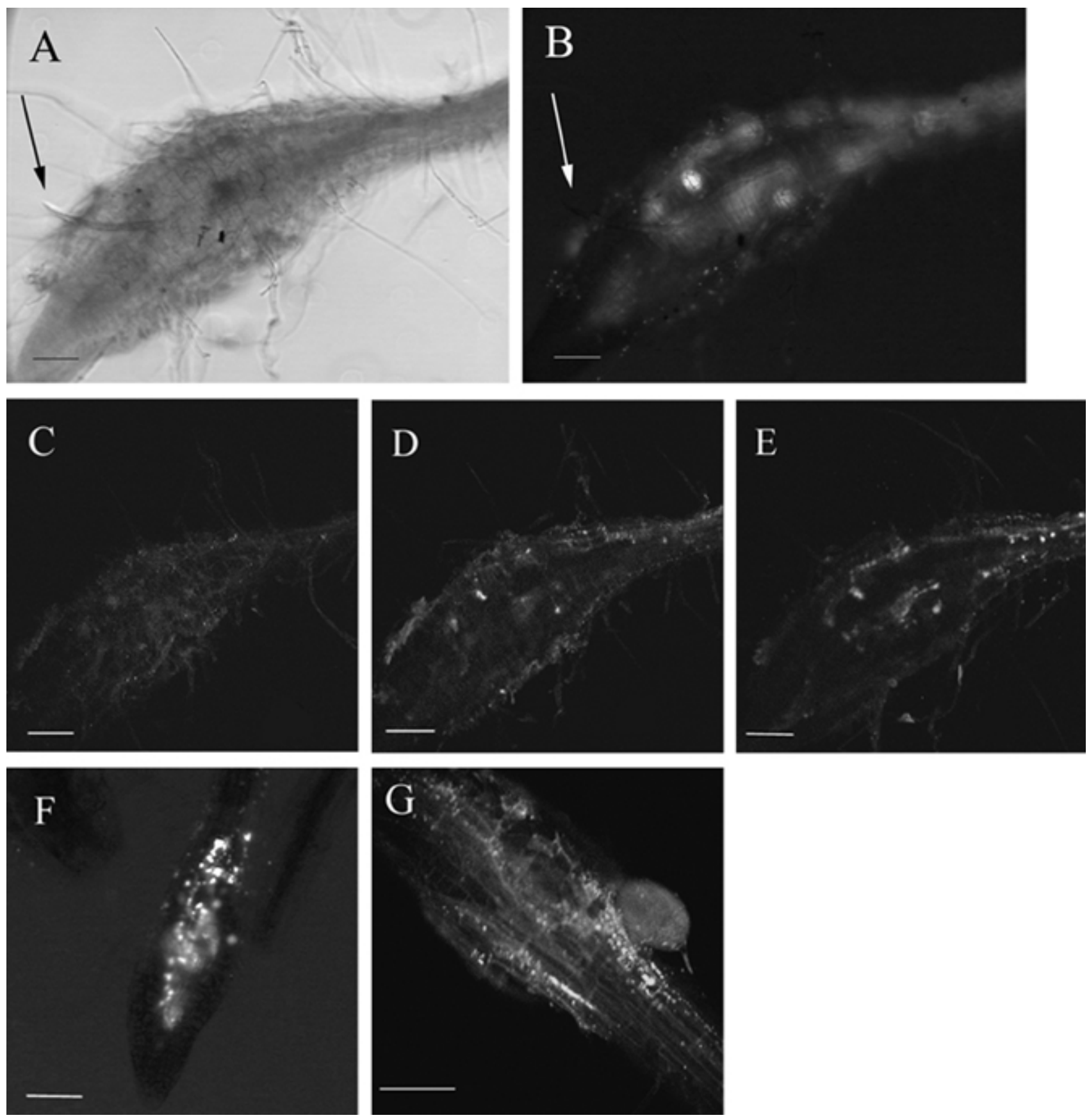

Fig. 9. Microscopic visualization of Rhizobium etli G12(pGT-trp) on and in root-knot nematode-infected Arabidopsis roots by epifluorescence and confocal laser scanning microscopy. Bacterial root colonization was visualized 12 days after bacterial application and 10 days after inoculation with Meloidogyne incognita. A, Bright field, and B, epifluorescence image of a nematode gall plus a penetrating juvenile (arrow) showing strong green fluorescent protein fluorescence within the galled tissue. A and B, Optical thin sections of the galled root section at various depths indicated: $\mathbf{C}$, no fluorescence at the root surface $(0 \mu \mathrm{m}) ; \mathbf{D}$, individual microcolonies at $80 \mu \mathrm{m}$; and $\mathbf{E}$, intense microbial colonization at $150 \mu \mathrm{m}$ showing strings of microcolonies. $\mathbf{F}$, Image of a root gall showing strong fluorescence due to colonization by G12(pGT-trp). G, Image of nematode gall with an adult nematode rupturing through the root tissue showing fluorescence around the nematode feeding site due to colonization by G12(pGT-trp). Magnification bars represent $100 \mu \mathrm{m}$. 
antagonist of the potato cyst nematode Globodera pallida (12), our results indicate it also can adversely affect the root-knot nematode $M$. incognita.

A heterogeneous colonization of G12(pGT-trp) may indicate induced systemic resistance as a second mode of action other than nutrient competition in biological control. Current research has shown that the lipopolysaccharides of $R$. etli G12 act as inducing agent of systemic resistance in potato toward the potato cyst nematode Globodera pallida (23). Similar mechanisms might be involved in the control of $M$. incognita. The internal colonization of G12(pGT-trp) would hereby support a strong and continuous signal transduction between bacterium and plant and that may enhance induced resistance by the plant. Despite several reports describing inter- and intracellular localization by endophytic bacteria $(9,13)$, our understanding of endophytic colonization of the total root system or even the whole plant is still very limited. GFP-tagging of bacteria now provides a powerful tool to study endophytic colonization of the entire plant.

\section{ACKNOWLEDGMENTS}

The German Science Foundation provided a travel grant for J. Hallmann. We thank D. Schichnes and S. Ruzin from the Biological Imaging Facility, University of California, Berkeley, for assistance in confocal scanning laser microscopy; S. Long from Stanford University for providing plasmid pVO131, O. Becker from University of California, Riverside, for providing $M$. incognita inoculum; and J. Leveau and $\mathrm{M}$. Marco for their helpful comments.

\section{LITERATURE CITED}

1. Assmus, B., Hutzler, P., Kirchhoff, G., Amann, R., Lawrence, J. R., and Harmann, A. 1995. In situ localization of Azospirillum brasilense in the rhizosphere of wheat with fluorescently labeled, rRNA-targeted oligonucleotide probes and scanning confocal laser microscopy. Appl. Environ. Microbiol. 61:1013-1019.

2. Bloemberg, G. V., O’Toole, G. A., Lugtenberg, B. J. J., and Kolter, R. 1997. Green fluorescent protein as a marker for Pseudomonas spp. Appl. Environ. Microbiol. 63:4543-4551.

3. Cormack, B. P., Valdivia, R. H., and Falkow, S. 1996. FACS-optimized mutants of the green fluorescent protein (GFP). Gene 173:33-38.

4. Denny, T. P. 1995. Involvement of bacterial polysaccharides in plant pathogenesis. Annu. Rev. Phytopathol. 33:173-197.

5. Ditta, G., Stanfield, S., Corbin, D., and Helinski, D. R. 1980. Broad host range DNA cloning system for gram-negative bacteria: Construction of a gene bank of Rhizobium meliloti. Proc. Natl. Acad. Sci. USA 77: 7347-7351.

6. Egener, T., Hurek, T., and Reinhold-Hurek, B. 1998. Use of green fluorescent protein to detect expression of nifGenes of Azoarcus sp. BH72, a grass-associated diazotroph, on rice roots. Mol. Plant-Microbe Interact. 11:71-75.

7. Elliot, L. F., Gilmour, C. M., Lynch, J. M., and Tittemore, D. 1984. Bacterial colonization of plant roots. Am. Soc. Agron. 47:1-16.

8. Gage, D. J., Bobo, T., and Long, S. R. 1996. Use of green fluorescent protein to visualize the early events of symbiosis between Rhizobium meliloti and alfalfa (Medicago sativa). J. Bacteriol. 178:7159-7166.

9. Hallmann, J., Quadt-Hallmann, A., Mahaffee, W. F., and Kloepper, J. W. 1997. Bacterial endophytes in agricultural crops. Can. J. Microbiol. 43:895-914.

10. Hallmann, J., Rodríguez-Kábana, R., and Kloepper, J. W. 1999. Chitinmediated changes in bacterial communities of the soil, rhizosphere and within roots of cotton in relation to nematode control. Soil Biol. Biochem. 31:551-560.

11. Hansen, M., Kragelund, L., Nybroe, O., and Sorensen, J. 1997. Early colonization of barley roots by Pseudomonas fluorescens studied by immunofluorescence technique and confocal laser scanning microscopy. FEMS Microbiol. Ecol. 23:353-360.

12. Hasky-Günther, K., Hoffmann-Hergarten, S., and Sikora, R. A. 1998. Resistance against the potato cyst nematode Globodera pallida systemically induced by the rhizobacteria Agrobacterium radiobacter (G12) and Bacillus sphaericus (B43). Fundam. Appl. Nematol. 21:511-517.

13. Hecht-Buchholz, C. 1998. The apoplast-habitat of endophytic dinitrogen-fixing bacteria and their significance for the nitrogen nutrition of nonleguminous plants. Z. Pflanzenernähr. Bodenkd. 161:509-520.

14. Heim, R., Cubitt, A. B., and Tsien, R. Y. 1995. Improved green fluorescence. Nature 373:663-664.

15. Huang, C. S. 1985. Formation, anatomy and physiology of giant cells induced by root-knot nematodes. Pages 154-164 in: An Advanced Treatise on Meloidogyne. Vol. 1. Biology and Control. J. N. Sasser and C. C. Carter, eds. North Carolina State University Graphics, Raleigh.

16. Hurek, T., Reinhold-Hurek, B., Van Montagu, M., and Kellenberger, E. 1994. Root colonization and systemic spreading of Azoarcus sp. strain BH72 in grasses. J. Bacteriol. 176:1913-1923.

17. Hussey, R. S., and Barker, K. R. 1973. A comparison of methods of collecting inocula for Meloidogyne spp., including a new technique. Plant Dis. Rep. 57:1025-1028.

18. Kloepper, J. W., and Beauchamp, C. J. 1992. A review of issues related to measuring colonization of plant roots by bacteria. Can. J. Microbiol. 38:1219-1232.

19. Mahaffee, W. F., and Kloepper, J. W. 1997. Temporal changes in the bacterial communities of soil, rhizosphere and endorhiza. Microb. Ecol. 34:210-233.

20. Miller, W. G., Leveau, J. H. J., and Lindow, S. E. 2000. Improved $g f p$ and inaZ broad-host-range promoter-probe vectors. Mol. Plant-Microbe Interact. 13:1243-1250.

21. Quadt-Hallmann, A., Benhamou, N., and Kloepper, J. W. 1996. Bacterial endophytes in cotton: Mechanisms of entering the plant. Can. J. Microbiol. 43:577-582.

22. Quadt-Hallmann, A., and Kloepper, J. W. 1996. Immunological detection and localization of the cotton endophyte Enterobacter asburia JM22 in different plant species. Can. J. Microbiol. 42:1144-1154.

23. Reitz, M., Rudolph, K., Schröder, I., Hoffmann-Hergarten, S., Hallmann, J., and Sikora, R. A. 2000. Lipopolysaccharides of Rhizobium etli strain G12 act as inducing agent of systemic resistance in potato towards infection by the cyst nematode Globodera pallida. Appl. Environ. Microbiol. 66:3515-3518.

24. Schloter, M., and Hartmann, A. 1998. Endophytic and surface colonization of wheat roots by different Azospirillum brasilense strains with strain-specific monoclonal antibodies. Pages 159-179 in: Proc. Int. Cong. Symbiosis, 2nd. Woods Hole, MS.

25. Thornton, B., and Macklon, A. E. S. 1989. Copper uptake by ryegrass seedlings: Contribution of cell wall adsorption. J. Exp. Bot. 40:1105-1111. 